\title{
Effects of sulphuric acid and hot water treatments on seed germination of tamarind (Tamarindus indica $\mathrm{L}$ )
}

\author{
S. Muhammad ${ }^{1 *}$ and N. A. Amusa ${ }^{2}$ \\ ${ }^{1}$ Department of Biological Sciences, Usmanu Danfodiyo University, Sokoto, Nigeria. \\ ${ }^{2}$ Institute of Agricultural Research and Training, Obafemi Awolowo University, P.M.B. 5029, Moor Plantation, Ibadan. \\ Nigeria.
}

Accepted 11 August 2003

\begin{abstract}
A study was carried out to investigate the effects of sulphuric acid and hot water treatments on the germination of Tamarind (Tamarindus indica L). Seeds were placed on moistened filter papers in 28 cm diameter Petri dishes under laboratory condition for germination. 330 seeds of $T$. indica (10 seeds per Petri dish) with three replicates each were used. The highest germination was recorded in seeds treated with 50 per cent sulphuric acid concentration with 60 min soaking period. Germination was observed to be enhanced by increase in the sulphuric acid concentration, water temperature, and soaking period in all the trials, except with absolute sulphuric acid where poor response was observed. Results of this study may serve as useful information in the production and improvement of the tree species, as knowledge on seed germination requirements is a critical factor in seedlings production.
\end{abstract}

Key words: Tamarind, Tamarindus indica, sulphuric acid, hot water, germination.

\section{INTRODUCTION}

Tamarindus indica Linn is an indigenous legume, which has been recognised as a potential nitrogen fixing tree in the semi-arid region of Nigeria (Okoro et al., 1986). It is important to rural communities as a major raw material for soft drinks and pharmaceuticals (Okoro et al., 1986). In Nigeria the growth and management of Tamarind is in the hands of local farmers. Nursery phases are an important part of the operation in the cultivation of many tropical tree crops (Ayodele, 1997). Keeping the seedlings growing in the nursery until they are big enough, tougher and more vigorous save seeds, space,

\footnotetext{
*Corresponding Author: E-mail: sanusi1966@yahoo.com.
}

water and reduces the risk of damage to or loss of the plant (Ayodele, 1997).

$T$. indica in Nigeria have been exploited more or less as wild form. The aging tree stands are gradually dying without replacements and seeds do not germinate of their own accord, possibly due to lack of the factor that is required to break the dormancy. To enhance rapid sustainable production of $T$. indica there is a need for an understanding of the basic sivilcutural requirements of the species. Knowledge on seed germination is known to be an important tool for any afforestation success. In addition, the role of $T$. indica in environmental protection can not be over emphasized. The wide spread canopy of the tree clearly shows its ability to provide protection from harsh whether as well as sheds for humans and livestock. This study was therefore designed to assess 
Table 1a. Effects of sulphuric acid treatments on the germination value, mean seed germination, and mean germination time of seeds of Tamarindus indica $\mathrm{L}$.

\begin{tabular}{|c|c|c|c|c|c|c|c|c|c|c|c|c|c|c|c|c|c|c|c|c|}
\hline \multirow{3}{*}{$\mathrm{H}_{2} \mathrm{SO}_{4}$ acid concentration } & \multicolumn{20}{|c|}{ Days of germination } \\
\hline & \multicolumn{4}{|c|}{3} & \multicolumn{4}{|c|}{6} & \multicolumn{4}{|c|}{9} & \multicolumn{4}{|c|}{12} & \multicolumn{4}{|c|}{15} \\
\hline & Mean & CMG & MGT & GV & Mean & CMG & MGT & GV & Mean & CMG & MGT & GV & Mean & $\mathrm{CMG}$ & MGT & GV & Mean & CMG & MGT & GV \\
\hline $98 \%$ (60mins) & 0 & 0 & 0 & 6 & 1 & 10 & 2 & 6 & 3 & 30 & 6 & 6 & 3 & 30 & 12 & 6 & 3 & 30 & 15 & 6 \\
\hline $98 \%$ (30mins) & 3 & 30 & 1.3 & 14 & 5 & 50 & 4.3 & 14 & 6 & 60 & 7.7 & 14 & 7 & 70 & 15 & 14 & 7 & 70 & 15 & 14 \\
\hline $49 \%$ (60mins) & .75 & 10 & .75 & 8 & 2 & 20 & 3 & 8 & 3 & 30 & 6.8 & 8 & 4 & 40 & 12 & 8 & 4 & 40 & 15 & 8 \\
\hline $49 \%$ (30mins) & 0 & 0 & 0 & 6 & 1 & 10 & 1 & 6 & 3 & 30 & 12 & 6 & 3 & 30 & 12 & 6 & 3 & 30 & 15 & 6 \\
\hline Control (untreated) & 0 & 0 & 0 & 4 & 0 & 0 & 4.5 & 4 & 1 & 20 & 4.5 & 4 & 2 & 20 & 12 & 4 & 2 & 20 & 15 & 4 \\
\hline
\end{tabular}

CMG: Cumulative \% Mean Germination

MGT: Mean Germination Time

GV: GerminationValue

Table 1b. Effects of hot water treatments on the germination value, mean seed germination, and mean germination time of seeds of Tamarindus indica L.

\begin{tabular}{|c|c|c|c|c|c|c|c|c|c|c|c|c|c|c|c|c|c|c|c|c|}
\hline \multirow{3}{*}{ Hot-water Treatment } & \multicolumn{20}{|c|}{ Days of germination } \\
\hline & \multicolumn{4}{|c|}{3} & \multicolumn{4}{|c|}{6} & \multicolumn{4}{|c|}{9} & \multicolumn{4}{|c|}{12} & \multicolumn{4}{|c|}{15} \\
\hline & Mean & CMG & MGT & GV & Mean & CMG & MGT & GV & Mean & CMG & MGT & GV & Mean & CMG & MGT & GV & Mean & CMG & MGT & GV \\
\hline $100^{\circ} \mathrm{C}$ for $60 \mathrm{mns}$ & 1 & 10 & .75 & 8 & 2 & 20 & 3 & 8 & 3 & 30 & 4.5 & 8 & 4 & 40 & 12 & 8 & 4 & 40 & 12 & 8 \\
\hline $100^{\circ} \mathrm{C}$ for $30 \mathrm{mns}$ & 2 & 20 & 1.2 & 10 & 2 & 20 & 2.4 & 10 & 3 & 30 & 5.4 & 10 & 4 & 40 & 4.6 & 10 & 5 & 50 & 15 & 10 \\
\hline $50^{\circ} \mathrm{C}$ for $60 \mathrm{mns}$ & 0 & 0 & 2 & 6 & 1 & 10 & 2 & 6 & 2 & 20 & 6 & 6 & 2 & 20 & 8 & 6 & 3 & 30 & 15 & 6 \\
\hline $50^{\circ} \mathrm{C}$ for $30 \mathrm{mns}$ & 0 & 0 & 2 & 4 & 1 & 10 & 2 & 4 & 2 & 20 & 6 & 4 & 2 & 20 & 8 & 4 & 3 & 20 & 15 & 4 \\
\hline Control (untreated) & 0 & 0 & 0 & 4 & 0 & 0 & 0 & 4 & 1 & 10 & 4.5 & 4 & 1 & 10 & 6 & 4 & 2 & 20 & 15 & 4 \\
\hline
\end{tabular}

CMG: Cumulative \% Mean Germination

MGT: Mean Germination Time

GV: GerminationValue 
the effects of hot water and sulphuric acid treatments on the seed germination of $T$. indica.

\section{MATERIALS AND METHODS}

The seeds of $T$. indica were collected using random sampling technique (RST) from 16 local government areas of Kebbi State in Nigeria. After dehuling the fruits, equal samples of seeds were combined to give one bulk population sample from which sub samples were taken for germination test. Seeds were germinated by placing them on wetted filter papers in $28 \mathrm{~cm}$ diameter petri dishes under laboratory condition $\left(32^{\circ} \mathrm{C} \pm 4^{\circ} \mathrm{C}\right)$. In each trial, 10 seeds per petri dish and five replicates were made for each method. Sulphuric acid seed and hot water treatments were used.

Sulphuric acid seed treatment was carried out to assess the effect of sulphuric acid concentration and time on germination performance. Two sulphuric acid concentrations (50\% and 100\%) and two treatment times ( 30 and $60 \mathrm{~min}$ ) were used, seeds were rinsed several times in clean distilled water and tested for germination (Yoursheng and Sziklai, 1985). The effect of hot water was carried out at two temperatures $\left(50\right.$ and $\left.100^{\circ} \mathrm{C}\right)$ and two treatment time (30 and $60 \mathrm{~min}$ ) after which the seeds were tested for germination (Awodola, 1994). A completely randomized design with three replications was used, while the dependent variables measured were $3,6,9,12$, and 15 days periods of germination.

The percentage germination was determined for each seed batch ( 5 replicates of 10 seeds) each placed on $28 \mathrm{~cm}$ diameter petri dishes with filter-paper and then watered slightly for 15 days. The cumulative percentage germination (CPG) and mean germination time (MGT) was calculated using the method of Younsheng and Sziklai (1985) as follows:

$\mathrm{MGT}=\sum \mathrm{nidi} / \mathrm{n}$

Where: $\mathrm{n}=$ total number of seeds germinated during 15-day experimental period; $\mathrm{ni}=$ number of seed germinated on day di; $\mathrm{di}=$ day during germination period (between 0 and 15).

The germination value (GV) was computed following the method of Djaranshir and Pourbeik (1976):

\section{GV, day-1 =DGS/N x CPG $\times 10$}

DGS=daily germination speed computed by dividing CPG by number of days since beginning the test; $N=$ frequency of DGS that are calculated during the test; $10=$ is a constant.

The data was subjected to the analysis of variance (ANOVA) and where there were significant differences among treatments, means separation was done using the Duncan's Multiple Range Test. (Steel and Torie, 1980)

\section{RESULTS AND DISCUSSION}

\section{Effect of sulphuric acid treatments}

The result of the experiment revealed that soaking of $T$. indica seeds in hot water at $100^{\circ} \mathrm{C}$ for 30 minutes had cumulative mean percentage germination (CMG) of $20 \%$ 3 weeks after germination. At 15 weeks after germination, the CMG was $50 \%$ (Table 1a). The CMG was also highest when $T$. indica seeds were soaked in $98 \%$ sulphuric acid concentration for a period of $30 \mathrm{~min}$, followed by soaking in $49 \%$ sulphuric acid concentration at for a period of $60 \mathrm{~min}$ (Table 1b). It was observed that seed germination increased with increasing acid concentration and treatment time (Table 2a). Treatment time exerted a significant effect on seed germination except with absolute sulphuric acid (98\%). A similar result was obtained by Awodola (1994). Germination percentage in seeds of $T$. indica was significantly enhanced by $50 \%$ sulphuric acid at all soaking periods. The highest germination percentage of 78.8 was recorded when seeds were treated with $50 \%$ sulphuric acid for 60 min (Table 2a)

Results also indicated that seed germination increased with increasing water temperature and soaking period (Table 2b). Significant differences were also found to

Table 2a. Effects of sulphuric acid treatments on seed germination of Tamarindus indica $\mathrm{L}$.

\begin{tabular}{|l|l|l|l|l|l|}
\hline \multirow{2}{*}{$\begin{array}{l}\text { Sulphuric Acid concentrations/ } \\
\text { period of soaking }\end{array}$} & \multicolumn{5}{|c|}{ Days (\% Germination) } \\
\cline { 2 - 6 } & 3 & 6 & 9 & 12 & 15 \\
\hline $98 \% \mathrm{H}_{2} \mathrm{SO}_{4}$ acid for $60 \mathrm{mns}$ & $9.8 \mathrm{~d}$ & $11.4 \mathrm{~d}$ & $13.8 \mathrm{~d}$ & $15.2 \mathrm{~d}$ & $17.8 \mathrm{~d}$ \\
$98 \% \mathrm{H}_{2} \mathrm{SO}_{4}$ acid for $30 \mathrm{mns}$ & $12.4 \mathrm{c}$ & $28.8 \mathrm{c}$ & $32.8 \mathrm{c}$ & $37.2 \mathrm{c}$ & $47.2 \mathrm{c}$ \\
$49 \% \mathrm{H}_{2} \mathrm{SO}_{4}$ acid for 60mns & $29.0 \mathrm{a}$ & $39.4 \mathrm{a}$ & $58.2 \mathrm{a}$ & $66.4 \mathrm{a}$ & $78.8 \mathrm{a}$ \\
$49 \% \mathrm{H}_{2} \mathrm{SO}_{4}$ acid for 30mns & $26.6 \mathrm{~b}$ & $32.4 \mathrm{~b}$ & $40.6 \mathrm{~b}$ & $57.2 \mathrm{~b}$ & $69.8 \mathrm{~b}$ \\
Control (untreated) & $1.4 \mathrm{e}$ & $1.4 \mathrm{e}$ & $1.4 \mathrm{e}$ & $6.4 \mathrm{e}$ & $5.8 \mathrm{e}$ \\
\hline
\end{tabular}

Means in a column with similar letters are not significantly different at $5 \%$ level of probability according to Duncan Multiple Range Test. 
Table $\mathbf{2 b}$. Effects of hot water treatments on seed germination of Tamarindus indica L.

\begin{tabular}{|c|l|l|l|l|l|}
\hline $\begin{array}{c}\text { Hot-water at } 100^{\circ} \mathrm{C} \text { and } \\
50^{\circ} \mathrm{C} / \text { period of soaking }\end{array}$ & \multicolumn{5}{|c|}{ Days (\% Germination) } \\
\hline & 3 & 6 & 9 & 12 & 15 \\
\hline Hot-water $\left(100^{\circ} \mathrm{C}\right)$ for $60 \mathrm{mns}$ & $28.2 \mathrm{a}$ & $38.9 \mathrm{a}$ & $48.2 \mathrm{a}$ & $56.20 \mathrm{a}$ & $69.0 \mathrm{a}$ \\
Hot-water $\left(100^{\circ} \mathrm{C}\right)$ for $30 \mathrm{mns}$ & $26.8 \mathrm{~b}$ & $33.2 \mathrm{~b}$ & $42.8 \mathrm{~b}$ & $51.20 \mathrm{~b}$ & $64.2 \mathrm{~b}$ \\
Hot-water $\left(50^{\circ} \mathrm{C}\right)$ for $60 \mathrm{mns}$ & $11.00 \mathrm{c}$ & $26.4 \mathrm{c}$ & $32.6 \mathrm{~b}$ & $38.2 \mathrm{c}$ & $49.8 \mathrm{c}$ \\
Hot-water $\left(50^{\circ} \mathrm{C}\right)$ for $30 \mathrm{mns}$ & $10.0 \mathrm{c}$ & $19.2 \mathrm{~d}$ & $22.2 \mathrm{c}$ & $27.0 \mathrm{~d}$ & $32.4 \mathrm{~d}$ \\
Control (untreated) & $2.2 \mathrm{~d}$ & $2.4 \mathrm{e}$ & $2.2 \mathrm{~d}$ & $8.0 \mathrm{e}$ & $6.2 \mathrm{e}$ \\
\hline
\end{tabular}

Means in a column with similar letters are not significantly different at $5 \%$ level of probability according to Duncan Multiple Range Test.

exist among all the treatments. Duguma et al. (1988) reported high percentage germination in seeds of Leucaenia leucocephala and Acacia nilotica with increasing ratio of seed weight to hot water volume.

We have shown that treatments of seed with sulphuric acid and hot water soaking are some factors that can significantly influence germination of $T$. indica. Hot water soaking gave higher percentage germination than ordinary water. Seed germination increased with increasing acid concentration and treatment time. The results obtained will be useful in carrying out tree improvement and plantings of tamarind trees for fuel wood, food, and local medicine production. Rapid seedling growth is also essential for anti-desertification. This information could ultimately help in the sustainable development of the arid zones.

\section{REFERENCES}

Awodola AM (1994). Aspects of germination in seeds of African locust bean tree Parkia biglobosa (Jacq) Don. J. Trop. Forest Resour. 10: 82-91.

Ayodele VI (1997). Substrates for production of ornamentals in Nigeria. Proceedings15th Hortson Conference, Ago - Iwoye, Ogun State, Nigeria.

Djavanshir K, Pourbeik H (1976). Germination value. A new formula. Silvae Genet. 25:79-83.

Duguma B, Kang BT, Okali DUU (1988). Factors affecting germination of Leucaena leuocephala. Seed Sci. Tech. 16:489-500.

Okoro SPA, Awodola AM, Itolo GO (1986). The impact of selected tree species on the soil properties in a Sudan Savanna Forest. Proceedings of 16th Annual Conference of Forestry Association of Nigeria. Pp. 660-667.

Steel R, Torie J (1980). Principles and proceedures of statistics. McGraw-Hill, New York, 144 pp.

Yoursheng C, Sziklai O (1985). Preliminary study on the germination of Toora sinensis (A.JUSS). Roem. Seed from eleven Chinese provenances. For. Ecol. Manage. 10: 269-281. 